\title{
Isolation and Characterization of Diamine Oxidase Enzyme from Mung Bean Sprouts (Vigna radiata L)
}

\author{
Abdul Karim ${ }^{1}$, Abd Rauf Patong ${ }^{1}$, Abd Wahid Wahab ${ }^{2}$, Indah Raya ${ }^{3}$ \\ ${ }^{1}$ Laboratory of Biochemistry, Chemistry Department, Mathematic and Natural Science Faculty, Hasanuddin Univesity, Makassar, Indonesia \\ ${ }^{2}$ Laboratory of Analytic chemistry, Chemistry Department, Mathematic and Natural Science Faculty, Hasanuddin Univesity, Makassar, \\ Indonesia \\ ${ }^{3}$ Laboratory of Inorganic chemistry, Chemistry Department, Mathematic and Natural Science Faculty, Hasanuddin Univesity, Makassar, \\ Indonesia
}

Email address:

karimkimia@yahoo.com (A. Karim)

\section{To cite this article:}

Abdul Karim, Abd Rauf Patong, Abd Wahid Wahab, Indah Raya. Isolation and Characterization of Diamine Oxidase Enzyme from Mung Bean Sprouts (Vigna radiata L). American Journal of Biomedical and Life Sciences. Vol. 3, No. 1, 2015, pp. 7-11. doi: $10.11648 /$ j.ajbls.20150301.12

\begin{abstract}
The diamine oxidase enzyme (DAO) can be isolated from mung bean sprouts (Vigna radiata L) through the process of extraction in phosphate buffer. Concentration and fractionation were performed by the addition of ammonium sulphate, $\left(\mathrm{NH}_{4}\right)_{2} \mathrm{SO}_{4}$ saturation in stages and cold centrifuged at $10000 \mathrm{rpm}$. Enzyme activity of DAO crude and DAO fractionation results were tested using substrat histamin and measured with a spectrophotometer at a wavelength of $450 \mathrm{~nm}$. This study revealed that the enzyme activity of the crude enzyme was $1,226 \mathrm{mU} / \mathrm{mL}$, the fraction of $40-60 \%$ ammonium sulphate saturated had the highest activity which accounted for $3326 \mathrm{mU} / \mathrm{mL}$ and after gel filtration, the results for both activity and specific activity were $116 \mathrm{mU} / \mathrm{mL}$ and $185 \mathrm{mU} / \mathrm{mg}$ protein.
\end{abstract}

Keywords: Diamine Oxidase, Mung Bean, Fractionation, Ammonium Sulphate

\section{Introduction}

The diamine oxidase enzyme (DAO, EC 1.4.3.6) catalyzes the oxidative deamination of histamine and other biogenic amines. DAO originally known as enzymes that degrade histamine levels so called histaminase. Although DAO plays an important role in the catabolism of histamine, but also efficiently convert many other diamine and expressed in many tissues. This enzyme catalyzes the oxidative deamination of primary amines to form an aldehyde, ammonia and hydrogen peroxide as shown in reaction (1) (Wilflingseder and Schwelberger, 2000).

$$
\mathrm{R}-\mathrm{CH}_{2}-\mathrm{NH}_{2}+\mathrm{H}_{2} \mathrm{O}+\mathrm{O}_{2} \stackrel{D A O}{\longrightarrow} \mathrm{R}-\mathrm{CHO}+\mathrm{NH}_{3}+\mathrm{H}_{2} \mathrm{O}_{2}
$$

Reaction (1) is the basis used in designing histamine biosensors to determine the amount of histamine contained in foods, especially fish and its derivatives. In biosensor histamine, DAO enzyme is one of the most important components. Measurement of oxygen consumption or production of hydrogen peroxyde and is commonly used for testing the activity of the DAO enzyme. Hydrogen peroxide is formed on the membrane layer of DAO enzyme under certain conditions which will diffuse toward the Pt electrode (anode). The amount of forming $\mathrm{H}_{2} \mathrm{O}_{2}$ is equal tothe histamine availability in solution (Mulchandani at al. 2001).

DAO enzyme has been found in several microorganisms such as bacteria, fungi, and the variety of plants and animals (Wimmerova and Macholan, 1999). DAO enzyme is also widely found in plants Leguminaceae (beans), as Cicerarietinum, Lathyrussativus and Vigna radiata (mung bean) (Choudhary et al, 1999) and was first purified by Mann (1955) of pea sprouts. This enzyme oxidizes diamine, such as histamine, and also some mono primary amines, with little or no activity against secondary and tertiary amine (Chang et al ,. 2008).

Currently, commercially available of DAO is obtained from pig kidney with a relatively low specific activity although it purified $(0.05 \mathrm{U} / \mathrm{mg})$, in contrast to the enzyme from plants which have a relatively higher activity. Two plants of the genus Lathyrus also been known to contain the enzyme DAO. Enzymes of Lathyrussativus first reported by Suresh et al., (1976). Substrate selectivity and sensitivity for several inhibitors of this enzyme is similar to the oxidase 
from pea and lentil (Medda et al., 1995).

This study was conducted to isolate and characterize the DAO enzyme from mung bean sprouts (Vignaradiata L). Isolation of DAO enzyme was involved a cold extraction in phosphate buffer solution $\mathrm{pH} 7.0$ and fractionated with ammonium sulphate at various levels of saturation and G75 sephadex gel filtration. Characterization is done by determining the DAO enzyme activity, $\mathrm{pH}$ and temperature optimum. Determination of DAO enzyme activity using the substrate histamine and o-dianisidin as color reagent then measured with a spectrophotometer at a wavelength of 450 $\mathrm{nm}$.

\section{Materials and Methods}

\subsection{Materials}

Materials used in this study is the mung bean (Vigna radiata $\mathrm{L}$ ), phosphate buffer, Sephadex G-75, BSA (Bovine Serum Albumin), Lowry Lowry A and B, histamine, HCl, odianisidin, HRP, standard DAO.

\subsection{Isolation of DAO Enzyme from Mungbean (Vignaradiata L.)}

\subsubsection{Crude Ekstract of DAO Enzyme}

A total of 100 grams of mung beans are washed and soaked in distilled water overnight. Furthermore, drained and leveled over a porous container lined with filter paper, let stand at humid room temperature. To assist the process of growing sprouts for quicker and evenly, the container can be placed in the pot (lid slightly open) or covered with a napkin and humidity maintained by sprinkling water on a regular basis. For the isolation and purification of the DAO enzyme of mung bean sprouts, sprouts age of 3 days was collected and washed with distilled water and the outer skin removed. Mung bean sprouts that have clean homogenized with an equal amount $(\mathrm{w} / \mathrm{v})$ of $50 \mathrm{mM}$ phosphate buffer $\mathrm{pH} 7.0$ in cold condition by using a blender. Crude extract obtained by squeezing homogenate through four layers of gauze and centrifuged at $10000 \mathrm{rpm}$ for $20 \mathrm{~min}$ at $4^{\circ} \mathrm{C}$. Results (solution) was called crude extract of DAO enzyme

\subsubsection{Ammonium Sulphate Fractionation}

DAO enzyme crude extract was fractionated with ammonium sulfate at a rate of $0-80 \%$ saturation with intervals of 20 units were added gradually while stirring with a magnetic stirrer to dissolve completely and left overnight at $4^{\circ} \mathrm{C}$. After which it was centrifuged at $4^{\circ} \mathrm{C}$ for 20 minutes. Supernatant obtained was continued for further fractionation, while the precipitate was dissolved in a small volume of 0.2 $\mathrm{M}$ phosphate buffer $\mathrm{pH}$ 7.0, and its activity is measured. Fraction having the highest activity followed by dialysis

\subsubsection{Dialysis}

Ammonium sulphate precipitate fraction with high activity was dissolved in $3 \mathrm{~mL}$ of $0.2 \mathrm{M}$ phosphate buffer $\mathrm{pH}$ 7.0. The solution was put in a cellophane bag and then dialyzed with $0.05 \mathrm{M}$ phosphate buffer $\mathrm{pH} 7.0$ and stirred with a magnetic stirrer for 12 hours at a temperature of $5^{\circ} \mathrm{C}$. Every 3 hours performed buffer replacement.

\subsubsection{Gel Filtration}

Active fraction which has undergone dialysis incorporated into the matrix column with sephadex G-75 (column length $35 \mathrm{~cm}$ and a diameter of $1 \mathrm{~cm}$ ), previously equilibrated with $0.05 \mathrm{M}$ phosphate buffer at $\mathrm{pH} 7.0$ for one night. Furthermore it eluted with the same buffer. The volume of each fraction as much as $3.0 \mathrm{ml}$ and each fraction was measured its activity and protein content. Fractions that have high activity saved and will be used as the DAO enzyme for further research

\subsection{Determination of DAO Enzyme Activity}

A number of $1.5 \mathrm{~mL}$ of o-dianisidin, $0.3 \mathrm{~mL}$ of $0.05 \mathrm{M}$ histamine and $0.2 \mathrm{~mL}$ peroxidase (HRP) 40 units $/ \mathrm{mL}$ were mixed into a clean test tube. The solution was preincubated in a water bath at $37^{\circ} \mathrm{C}$ for a few minutes for the temperature balance. Furthermore, $0.2 \mathrm{~mL}$ of sample (the amount of diamine oxidase unknown) pipetted into a test tube and the solution was stirred using a vortexer. The reaction was allowed to proceed at $37^{\circ} \mathrm{C}$ for exactly 10 minutes. The reaction was stopped by adding $0.2 \mathrm{~mL}$ of $4 \mathrm{M} \mathrm{HCl}$ and the solution was stirred using a vortexer end. The intensity of the color formed was measured with a spectrophotometer to read absorbance at $450 \mathrm{~nm}$ (A450). Diamine oxidase activity in the sample is determined from the calibration curve. One unit (1 U) of activity causes the oxidation of o-dianisidin 1 micromoles per minute under specified conditions (at $37^{\circ} \mathrm{C}$ and $\mathrm{pH}$ 7.4). To create a calibration curve, $0.2 \mathrm{~mL}$ of sample (the amount of diamine oxidase unknown) from the previous step is replaced with a standard $0.2 \mathrm{~mL}$ of diamine oxidase is known. Standard diamine oxidase is made varies between 50 $500 \mathrm{mU}$.

\subsection{Protein Measurement}

Determination of protein content using the Lowry method. Protein sample solution in $1 \mathrm{~mL}$ put into a test tube and added $2.5 \mathrm{~mL}$ B. Lowry reagent solution was homogenized and allowed to stand at room temperature $\left(27^{\circ} \mathrm{C}\right)$ for 10 minutes. After that add $0.25 \mathrm{~mL}$ reagent of Lowry A and homogenized. Tubes were incubated at room temperature for returned 30 minutes, and then the absorbance was measured with a UV-Vis spectrophotometer at $\lambda=680 \mathrm{~nm}$. The protein content was determined by BSA (Bovine Serum Albumin) as standard.

\subsection{Determination of Optimum pH}

Determination of the optimum $\mathrm{pH}$ of DAO enzyme activity conducted at various $\mathrm{pH}$ range of 6.2 to 7.8 at intervals of $0.4 \mathrm{pH}$ units. A total of $0.2 \mathrm{~mL}$ of the DAO enzyme incubated into $1 \mathrm{~mL}$ of buffer solution from $\mathrm{pH} 6.2$ to 7.8 and $0.3 \mathrm{~mL}$ of histamine at $37^{\circ} \mathrm{C}$. Furthermore, the filtrate (buffer solution and a solution of histamine) was added to the cuvette containing: $1.5 \mathrm{~mL}$ of a mixture of odianisidin-buffer from $\mathrm{pH} 6.2$ to 7.8 and $0.2 \mathrm{~mL}$ peroxidase 
40 Units $/ \mathrm{mL}$, which was incubated for $5 \mathrm{~min}$ at $37^{\circ} \mathrm{C}$. Then the color uptake measured using a spectrophotometer at a wavelength of $450 \mathrm{~nm}$ (Hatzinikolaou and Macris, 1995)

\subsection{Determination of Optimum Temperature}

Determination of the optimum temperature of DAO enzyme activity performed at various temperature range of $25^{\circ} \mathrm{C}$ to $41^{\circ} \mathrm{C}$ with temperature interval of 4 units. A total of $0.2 \mathrm{~mL}$ of the DAOenzyme incubated into $1 \mathrm{~mL}$ of buffer solution at $\mathrm{pH} 7.4$ and $0.3 \mathrm{~mL}$ of histamine at a temperature of $25^{\circ} \mathrm{C}-41^{\circ} \mathrm{C}$. Furthermore, the filtrate (buffer solution and a solution of histamine) was added to the cuvette containing: $1.5 \mathrm{~mL}$ of a mixture of o-dianisidin-buffer at $\mathrm{pH} 7.4$ and 0.2 $\mathrm{mL}$ peroxidase $40 \mathrm{U} / \mathrm{mL}$ were incubated for $5 \mathrm{~min}$ at $37^{\circ} \mathrm{C}$. Then the color uptake measured using a spectrophotometer at a wavelength of $450 \mathrm{~nm}$.

\section{Results and Discussions}

\subsection{Crude Extract}

DAO enzyme extraction of mung bean sprouts obtained the results as shown in Table 1 . In Table 1 shows that the protein content of the crude extract of $25.20 \mathrm{mg} / \mathrm{mL}$ and 1286 $\mathrm{mU} / \mathrm{mL}$ of DAO enzyme activity. These results are quite large and can proceed to the next stage of fractionation with ammonium sulphate.

As it is known that ammonium sulfate is a salt that is commonly used in the method of purification and concentration of enzyme. This is due to ammonium sulfate has several advantages such as high solubility, low-cost, low toxicity to most of the enzyme and has a stabilizing effect on some enzymes (Mutiah, 2005).

The addition of ammonium sulfate done slowly at a temperature of $4^{\circ} \mathrm{C}$ while in-stirrer due to the increase in temperature due to the dissolution process assisted magnetic stirrer can cause denaturation and solubility changes. Selection of temperature $4 \mathrm{oC}$ to prevent damage to the enzyme.

Table 1. The concentration of protein and crude extract of the DAO enzyme activity.

\begin{tabular}{ll}
\hline [Protein] $(\mathbf{m g} / \mathbf{m L})$ & Activity DAO $(\mathbf{m U} / \mathbf{m L})$ \\
\hline 25.20 & 1286 \\
\hline
\end{tabular}

\subsection{Ammonium Sulphate Fractionation}

Fractionation with ammonium sulfate saturation were made at intervals of up to $80 \%$ with 20 units. In the process of fractionation, the $40-60 \%$ saturated fraction showed the highest activity at $3326 \mathrm{mU} / \mathrm{ml}$. Therefore the fraction of 40 $60 \%$ saturated selected for selannjutnya performed gel filtration to obtain a more pure fractions. Having calculated using the obtained standard protein content was $29.03 \mathrm{mg} /$ $\mathrm{ml}$. When compared with the protein content of the crude extract of the protein content of $40-60 \%$ saturated fraction is greater. It can be explained that in addition to some impurities already separated, the volume is also much smaller.
Table 2. DAO enzyme activity and protein concentration of each fraction.

\begin{tabular}{lll}
\hline Fraction(\% saturated) & DAO Act. $(\mathbf{m U} / \mathbf{m L})$ & [Protein] $(\mathbf{m g} / \mathbf{m L})$ \\
\hline $0-20$ & 2336 & 20.49 \\
$20-40$ & 2042.67 & 24.34 \\
$40-60$ & 3326 & 29.03 \\
$60-80$ & 1329.33 & 24.65 \\
\hline
\end{tabular}

\subsection{Gel Filtration}

The results of the protein content of each fraction measurements can be seen in Table 3. Gel filtration is intended to separate the enzyme proteins by size. Molecules move through porous granular layer, smaller molecules spread farther into the pores and therefore move more slowly, while larger molecules move faster.

Table 3. Measurement of protein content of 40-60\% saturated (fractions 1 30).

\begin{tabular}{llll}
\hline $\begin{array}{l}\text { Fraction } \\
\text { numbers }\end{array}$ & $\begin{array}{l}\text { [Protein] } \\
(\mathbf{m g} / \mathbf{m L})\end{array}$ & $\begin{array}{l}\text { Fraction } \\
\text { numbers }\end{array}$ & $\begin{array}{l}{[\text { Protein] }} \\
(\mathbf{m g} / \mathbf{m L})\end{array}$ \\
\hline 1 & 0.096 & 16 & 0.541 \\
2 & 0.579 & 17 & 0.427 \\
3 & 2.928 & 18 & 0.294 \\
4 & 6.751 & 19 & 0.207 \\
5 & 5.797 & 20 & 0.118 \\
6 & 1.35 & 21 & 0.108 \\
7 & 0.497 & 22 & 0.092 \\
8 & 0.446 & 23 & 0.084 \\
9 & 0.553 & 24 & 0.082 \\
10 & 0.673 & 25 & 0.079 \\
11 & 0.661 & 26 & 0.068 \\
12 & 0.563 & 27 & 0.065 \\
13 & 0.545 & 28 & 0.065 \\
14 & 0.627 & 29 & 0.067 \\
15 & 0.625 & 30 & 0.056 \\
\hline
\end{tabular}

To facilitate reading and see the tendency of each fraction of the protein content of it is made in the form of curves. The curve measuring the protein content of $40-60 \%$ saturated (fractions 1-30) can be seen in Figure 1.

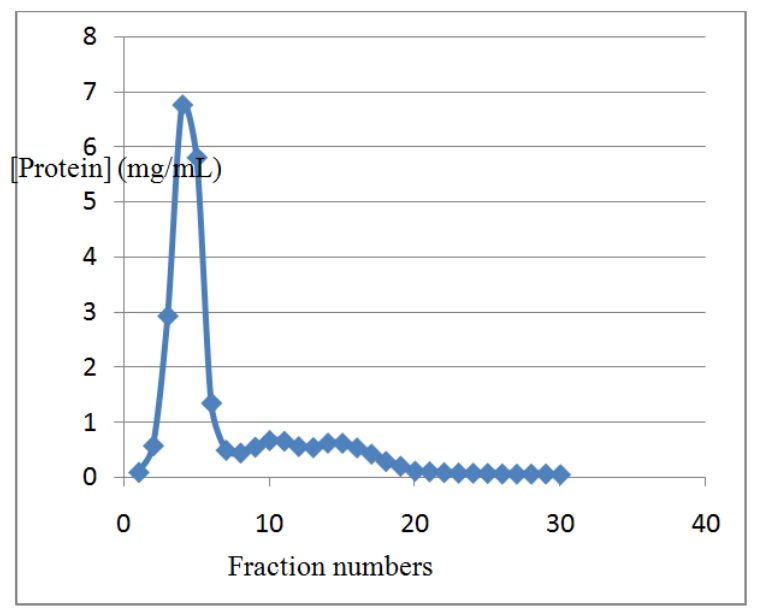

Figure 1. Graph between protein content vs. fraction numbers.

Figure 1shows that there was a peak (high protein) in fraction number 4 is $6.751 \mathrm{mg} / \mathrm{mL}$ and also a trend of two other peaks in fraction numbers $10-11$ and 14-15 fraction 
numbers. After the protein content decreases and the fraction numbers 21-30 is relatively constant. Because the measurement of the activity/DAO enzyme concentration will be undergone at the peak fraction (Table 4).

Table 4. The concentration of proteins and DAO enzyme activity after gel filtration.

\begin{tabular}{llll}
\hline $\begin{array}{l}\text { Fraction } \\
\text { numbers }\end{array}$ & $\begin{array}{l}\text { [Protein] } \\
(\mathbf{m g} / \mathbf{m L})\end{array}$ & $\begin{array}{l}\text { DAO Activity } \\
(\mathbf{m U} / \mathbf{m L})\end{array}$ & $\begin{array}{l}\text { Specific Activity } \\
(\mathbf{m U} / \mathbf{m g})\end{array}$ \\
\hline 3 & 2.928 & 56 & 19.13 \\
4 & 6.751 & 79.33 & 11.75 \\
5 & 5.797 & 59.33 & 10.24 \\
6 & 1.315 & 56 & 42.59 \\
10 & 0.673 & 39.33 & 58.44 \\
11 & 0.661 & 46 & 69.59 \\
14 & 0.627 & 116 & 185.00 \\
15 & 0.625 & 86 & 137.60 \\
\hline
\end{tabular}

In Table 4 shows that the protein content is not directly proportional to the DAO enzyme activity. The fraction 4 with the highest protein content $(6.751 \mathrm{mg} / \mathrm{mL})$ have DAO activity at $79.33 \mathrm{mU} / \mathrm{mL}$ and specific activity for only 11.75 $\mathrm{mU} / \mathrm{mg}$ protein. While the fraction 14 with the protein content of $0.627 \mathrm{mg} / \mathrm{mL}$ have DAO activity at $116 \mathrm{mU} / \mathrm{mL}$ and specific activity of $185 \mathrm{mU} / \mathrm{mg}$ protein. It occurs because the DAO enzyme protein has experienced separation from the other components of the protein, thus also has higher specific activity.

\subsection{The Effect of $\mathrm{pH}$ on the DAO Enzyme Activity}

In figure 2 shows that the DAO enzyme activity increased to $\mathrm{pH} 7.4$ (optimum $\mathrm{pH}$ ) with the activity of $116 \mathrm{mU} / \mathrm{mL}$ and at $\mathrm{pH} 7.8$ in which the activity decreased to $81 \mathrm{mU} / \mathrm{mL}$. This shows that at $\mathrm{pH}$ less than or greater than the optimum $\mathrm{pH}$ will cause a conformational change in the enzyme so that its activity decreases. The results showed that the optimum $\mathrm{pH}$ of the DAO enzyme of mung beans is almost the same as the DAO enzyme of Euphorbia latex is 7.1 (Rinaldi, et al, 1982). Thus it can be stated that the DAO enzyme activity takes place in a relatively neutral conditions.

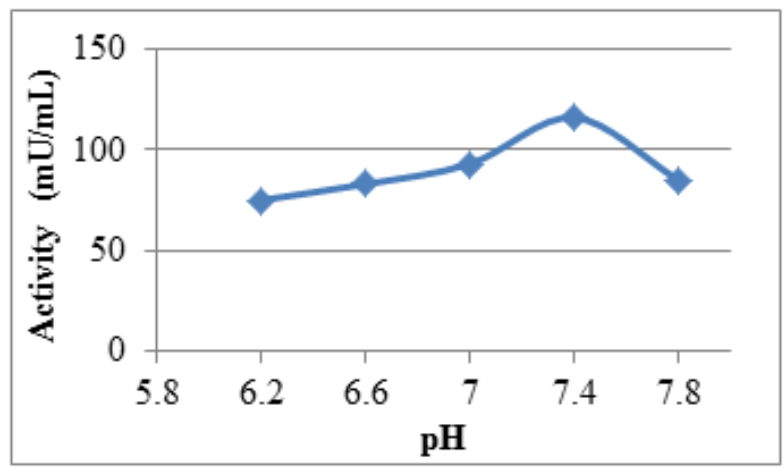

Figure 2. Effect of pH on the DAO enzyme activity.

Changes in $\mathrm{pH}$ causes changes in the charge of amino acid residues in a protein enzyme that serves to bind the substrate so as to affect its activity. If a negatively charged enzyme action with the positively charged substrate forming enzyme- substrate complex, then at low $\mathrm{pH}$ enzyme will protonated and negative charge which causes the loss of activity will decline. In contrast to the high $\mathrm{pH}$ of the substrate to be ionized and loses its positive charge so difficult enzymesubstrate complex is formed (Murray, et.al, 2009). Changes in $\mathrm{H}^{+}$ions in the solution affect the active enzyme and enzyme conformation. At $\mathrm{pH}$ is too low or too high cause conformational changes of enzymes that enzyme activity declined even to disappear.

The enzyme has a dissociation constant of the acid groups or basic groups, especially at the carboxyl and amino terminal residues. In a chemical reaction, the $\mathrm{pH}$ of an enzyme should not be too acidic nor too alkaline because it will decrease the rate of reaction with the denaturation. However, some enzymes operate in acid or alkaline state. For example, pepsin, an enzyme that is released into the stomach, can only function under acidic conditions, the optimum $\mathrm{pH} 2$ (Gaman and Sherrington, 1994)

\subsection{The Effect of Temperature on the DAO Enzyme Activity}

In figure 3 shows that the DAO enzyme activity increases with increasing temperature up to $37 \mathrm{oC}$ (optimum temperature) with the activity of $116 \mathrm{mU} / \mathrm{mL}$. After passing the optimum temperature, activity back down and the temperature $390 \mathrm{C}$ enzyme activity to $73 \mathrm{mU} / \mathrm{mL}$.

Addition of temperature causes an increase in the kinetic energy of molecules of substances that react and lead to higher activity. However, at higher temperatures, higher kinetic energy will break secondary bonds that maintain the structure of the enzyme in the nature form. As a result, decreased enzyme activity that will eventually be lost.

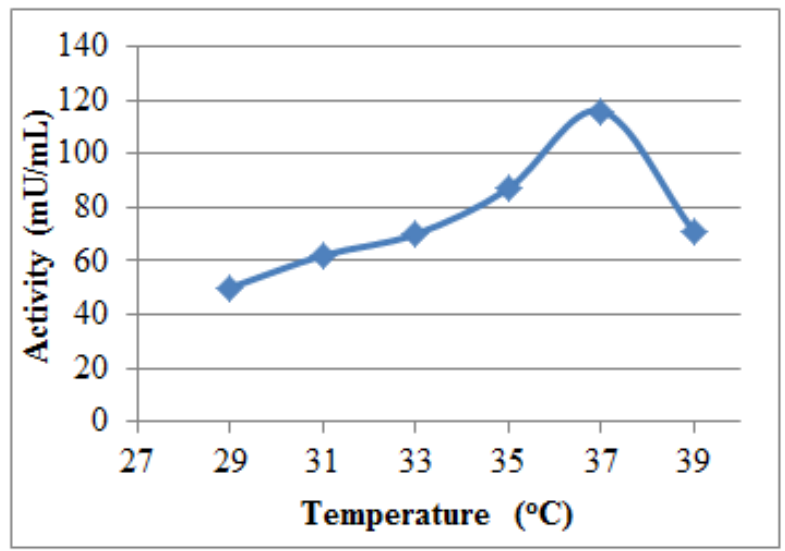

Figure 3. Effect of temperature on the DAO enzyme activity.

Addition temperature will also affect the hydrogen bonding or hydrophobic interactions that maintain the conformation of the enzyme molecule. Enzyme conformational changes will affect the active side. At a certain temperature conditions cause. The breakdown of the hydrogen bond would cause subsequent hydrogen bonds in the polypeptide chain will be more easily broken. And so on so that the protein will undergo denaturation and enzyme activity is lost (Whitaker, 1994)

Increasing temperatures can enlarge the rate of reaction 
because the atomic molecules have greater energy and have a tendency to move. As the temperature increases, the denaturation process also began to take place and destroy the activity of the enzyme molecule. This is because the protein chain that is not folded after the termination of the weak bonds so that the overall reaction rate will decrease (Lee, 1992).

\section{Conclusion}

1. The DAO enzyme can be obtained from mung bean sprouts through cold extraction process in phosphate buffer at $\mathrm{pH} 7.0$ with sufficiently high activity, 1286 $\mathrm{mU} / \mathrm{ml}$

2. Fraction of $40-60 \%$ ammonium sulfate saturated showed the highest activity at $3326 \mathrm{mU} / \mathrm{mL}$.

3. Filtration gel with sephadex G-75 resulted in a more pure DAO enzyme with activity of $116 \mathrm{mU} / \mathrm{mL}$ and specific activity of $185 \mathrm{mU} / \mathrm{mg}$ protein, optimum $\mathrm{pH}$ at 7.4 and optimum temperature of $37^{\circ} \mathrm{C}$.

\section{Acknowledgements}

The author would like to thank Mahdalia and Hasna Natsir as analyst and head of the Biochemistry Laboratory of Hasanuddin University who has helped the technical and research facilities in particular the isolation and characterization of the DAO enzyme. Thanks are also extended to the Directorate General of Higher Education (DGHE) and Graduate Program, Hasanuddin University which provides scholarship funds through the Agency of Domestic Educational Administrator (ADEA)

\section{References}

[1] Chang, A., Scheer, M., Grote, A., Schomburg, I., Schomburg, D., 2008, Brenda, Amenda and Frenda the enzyme information system: new content and tools in 2009. Nucleic Acids Res. 37:588-592.

[2] Choudhary, A., Singh, I. and Sigh, R. P., 1999, A thermostable Diamine Oxidase from Vignaradiata Seedlings. Phytochemistry. 52: 1-5.
[3] Choudhary, A., Singh, R.P., 2013, Cadmium-induced Changes in Diamine Oxidase Activity and Polyamine Levels in VignaradiataWilczek Seedlings, Journal of Plant Physiology, 156: $704-710$

[4] Gaman, P.M and K.B. Sherrington.(1994). Ilmu Pangan, Pengantar Ilmu Pangan, Nutrisidan Mikrobiologi. Universitas Gadjah Mada press. Yogyakarta.

[5] Lee, J. M. (1992). Biochemical Engineering.Prentice Hall Inc. New Jersey.

[6] Medda, R., Padiglia, A. and Floris, G.,1995, Plant Copper amine Oxidases. Phytochemistry. 39: 1-9.

[7] Mulchandani, A. and Rogers, R., 2001, Enzyme and Microbial Biosensors; Techniques and Protocols, Humana Press Inc., New Jersey

[8] Mutiah, D., 2005, Ultrafiltrasi, Presipitasi Bertingkat dan Kromatografi Penukar Ion sebagai Tahapan Pemurnian Enzim Protease Bacillus megaterium MS-961, Fakultas Teknologi Pertanian Institut Pertanian Bogor.

[9] Murray, R.K., Granner, D.K., and Victor, R.W., 2009, Biokimia Harper, EGC Penerbit Buku Kedokteran, Jakarta, 68-69

[10] Padiglia, A., Cogoni, A.and Floris, G., 1991, Characterization of Amine Oxidases from Pisum, Lens, Lathyrus and Cicer. Phytochemistry. 30: 3895-3897

[11] RINALD1, A., FLORIS, G.,and FINAZZI, A., 1982, Purification and Properties of Diamine Oxidase from Euphorbia latex, Eur. J. biochem, 127, 417-422

[12] Suresh, M. R., Ramakrishna, S. and Adiga, P. R., 1976, Diamine Oxidase of Lathyrussativus Seddlings. Phytochemistry. 15: 483-485.

[13] Wilflingseder, D. and Schwelberger, G., 2000, High Efficient Purification of Porcine Diamine Oxidase.Journal of Chromatography. 737:.161-166.

[14] Whitaker, R.J., 1994, Principle of Enzymology for the Food Sciences, Mergel Dekker inc, New York.

[15] Wimmerova. M. and Macholan, L., 1999, Sensitive Amperometric Biosensor for the Determination of Biogenic and Synthetic Amines Using Pea Seedlings Amine Oxidase: A Novel Approach for Enzyme Immobilization. Biosensor and Bioelectronics. 14: 695-702 